\title{
Endometrial expression of steroid receptors in postmenopausal hormone replacement therapy users: relationship to bleeding patterns
}

\author{
Susheel Vani, Hilary O D Critchley, Ian S Fraser, Martha Hickey
}

\begin{abstract}
Background Mechanisms of menopausal hormone replacement therapy (HRT)-related bleeding, undoubtedly mediated through endometrial steroid receptors, are poorly understood. We aimed to determine the steroid receptor expression in HRT-exposed endometrium in relation to disturbances of bleeding patterns.
\end{abstract}

Methods Prospective observational study in a tertiary referral menopause clinic in Western Australia. Thirtyeight outpatient endometrial biopsies (seven from women not on HRT, 31 from HRT users) were collected from 21 postmenopausal women during and outside bleeding episodes. Eleven women provided multiple biopsies. We performed an immunohistochemical analysis of endometrial glandular, stromal, epithelial, perivascular and endothelial expression of progesterone receptor (PR), glucocorticoid receptor (GR), androgen receptor (AR), estrogen receptors $\alpha$ and $\beta$ (ER $\alpha$ and $E R \beta)$ and studied their relationship to bleeding patterns.
Results In HRT users, during a bleeding episode, there was a trend (non-significant) towards a decrease in PR and an increase in GR in endometrial glandular cells. No differences were observed in AR and ER expression.

Conclusions We have been unable to demonstrate significant differences in steroid receptor expression in endometrium of women using HRT who report unscheduled bleeding episodes. These observations differ from the endometrial steroid receptor expression observed with normal menstruation and long-term progestogen-only administration, suggesting that different local mechanisms are involved in HRT-related unscheduled bleeding.

Keywords endometrium, hormone replacement therapy, postmenopausal, steroid receptors, unscheduled bleeding

J Fam Plann Reprod Health Care 2008; 34(1): 27-34 (Accepted 12 September 2007)

\section{Introduction}

Hormone replacement therapy (HRT) is used by peri- and postmenopausal women for the relief of menopausal symptoms and the prevention of osteoporotic fractures. The main therapeutic benefit is derived from estrogen but progestogen is necessary to prevent endometrial hyperplasia and adenocarcinoma. The majority of postmenopausal women take a continuous combined estrogen plus progestogen therapy that aims to avoid any vaginal bleeding. However, unpredictable and unscheduled vaginal bleeding or spotting is a common side effect described by up to $60 \%$ of HRT users, ${ }^{1}$ leading to discontinuation of therapy in up to one in three users. ${ }^{2}$ Over $30 \%$ of cyclic HRT users and nearly half of all continuous combined HRT users make at least one visit to their gynaecologist with irregular bleeding. ${ }^{3}$ In the majority of cases no pathology is found. 4

In the Women's Health Initiative study, a prospective double-blinded trial to assess the major health benefits and risks of the most commonly used combined hormone preparations in the USA, irregular bleeding was responsible for un-blinding in almost $40 \%$ of women

University of Edinburgh Centre for Reproductive Biology, The Queen's Medical Research Institute, Edinburgh, UK

Susheel Vani, MRCOG, FRCS, Clinical Research Fellow

Hilary O D Critchley, MD, FRCOG, Professor of Reproductive Medicine

Department of Obstetrics and Gynaecology, University of Sydney, Sydney, Australia

Ian S Fraser, MD, FRANZCOG, Professor in Reproductive Medicine

School of Women's and Infants' Health, University of Western Australia, Subiaco, Australia

Martha Hickey, MD, FRANZCOG, Professor

Correspondence to: Professor Hilary Critchley, University of Edinburgh Centre for Reproductive Biology, Queen's Medical Research Institute, Little France Crescent, Edinburgh EH16 4TJ, UK. E-mail: Hilary.Critchley@ed.ac.uk

\section{Key message points}

- Endometrial steroid receptor expression in hormone replacement therapy (HRT) users differs from that observed with normal menstruation and long-term progestogen-only administration.

- Different mechanisms are likely to be involved in HRTrelated unscheduled bleeding.

assigned to receive estrogen plus progestogen therapy. 5 Irregular vaginal bleeding tends to settle with prolonged use, but since many national guidelines now advise restricting use of HRT to less than 5 years, unscheduled bleeding is likely to continue to be a clinical problem.

There are no established ways of predicting, avoiding or treating unscheduled bleeding on HRT.6,7 Few studies have addressed the potential mechanisms of HRT-induced bleeding and the underlying mechanisms are poorly understood. We have reported changes in endometrial vascular density and perivascular support as well as increased numbers of stromal natural killer cells and an altered balance of matrix metalloproteinases to their tissue inhibitors, which may contribute to vascular breakdown and unscheduled bleeding in some HRT users. ${ }^{8,9}$ Human endometrium is a target for steroid hormones. Endometrial shedding and repair are considered inflammatory processes and sex steroids and glucocorticoids, acting via their receptors, are thought to play a vital role in the processes involved. ${ }^{10}$

Sex steroid receptor expression undergoes significant changes in regular cycling women, after treatment with exogenous estrogens and progestogens and in the presence or absence of breakthrough bleeding. ${ }^{10,11}$ Both endometrial oestrogen and progesterone receptors (ER $\alpha$ and PR) are up-regulated in stromal and glandular cells during the proliferative phase and subsequently downregulated in the glandular compartment during the secretory phase. ${ }^{12} \mathrm{PR}$ expression persists in the stromal cells in the secretory phase. PR protein has not been identified in the endometrial vascular endothelium. ${ }^{13}$ 
Table 1 Details of endometrial biopsy numbers

\begin{tabular}{lrl}
\hline & Women $(\boldsymbol{n})$ & Biopsies $(\boldsymbol{n})$ \\
\hline Women providing one biopsy & 10 & 10 \\
Women providing two biopsies & 5 & 10 \\
Women providing three biopsies & 6 & 18 \\
Total & 21 & 38 \\
\hline
\end{tabular}

Progesterone receptors are, however, abundantly expressed in the perivascular endometrial cells throughout the cycle. ${ }^{14,15}$ We have previously shown that both forms of the ER are expressed in the perivascular cells, but only $\mathrm{ER} \beta$ is present in endometrial endothelial cells. ${ }^{15}$

Endometrial stromal and endothelial cells express the GR. ${ }^{16,17}$ During the menstrual cycle, the AR is expressed in endometrial stromal cells and intensity of AR immunostaining is greater during the proliferative as compared to the secretory phase. ${ }^{18}$

The aim of this study was to investigate whether a relationship exists between endometrial steroid receptor expression and bleeding patterns in HRT users.

\section{Methods}

Thirty-eight endometrial biopsies were obtained from 21 postmenopausal women. Biopsies were obtained from seven postmenopausal women with at least 12 months of amenorrhea who had not been exposed to any hormonal treatments in the previous 90 days. These latter postmenopausal subjects, not receiving HRT, were included as controls for comparative purposes of the effects of HRT exposure on the postmenopausal endometrium. A further 31 biopsies were obtained from 14 postmenopausal women using continuous combined HRT. Eleven women gave multiple biopsies (Table 1). Multiple biopsies were obtained in order to compare sex steroid receptor expression during and outside a bleeding episode in the same subject. Biopsies with adequate tissue for analysis were selected to represent the clinical categories of no HRT use (Group 1), HRT use with no bleeding (Group 2), HRT use with irregular bleeding (Group 3) and HRT use with irregular bleeding biopsied during a bleeding episode (Group 4) (Table 2). A detailed medical history including bleeding patterns and current and previous HRT use was obtained from all the women. Bleeding diaries were prospectively completed over a 90-day reference period and bleeding patterns classified as either 'no bleeding' or 'irregular bleeding'. Irregular bleeding was defined as any vaginal bleeding occurring in postmenopausal continuous combined HRT users after at least 3 months of HRT use. The study was restricted to those women using oral or transdermal HRT and the range of products used are documented in Table 3. Women were excluded if they were taking any herbal or other therapy that might alter endometrial histology.

Compliance with the HRT medication was monitored during this period and women were excluded if they did not take their HRT preparation strictly according to the manufacturer's instructions (daily for oral preparations or twice-weekly for transdermal preparations). Those with irregular bleeding were asked to contact the research nurse during bleeding episodes so that biopsies could be obtained both during and outside bleeding episodes. Irregular bleeding in HRT users was investigated according to standard hospital protocols. In brief, a Pap smear was obtained and transvaginal pelvic ultrasound arranged. If the endometrial thickness was $\leq 6 \mathrm{~mm}$, an endometrial biopsy was obtained to assess histology. If the endometrium was $>6 \mathrm{~mm}$, hysteroscopy and endometrial biopsy were performed.

These women represent a subset from a larger study of bleeding mechanism on HRT from the Menopause Clinic at King Edward Memorial Hospital (KEMH, Perth, Western Australia) between 2003 and 2005.8,9

Biopsies were fixed immediately in $10 \%$ formalin for 18 hours and tissue was then embedded in paraffin. Sections were cut at $5 \mu \mathrm{m}$. The sections were dried at $37^{\circ} \mathrm{C}$ overnight. All biopsies had a standard haematoxylin and eosin section submitted to an experienced histopathologist for classification according to Noyes criteria ${ }^{19}$ and for identification of any pathological features.

\section{Immunohistochemistry}

Immunostaining for the tissue localisation of each steroid receptor was performed separately. Paraffin-embedded tissue sections were dewaxed, rehydrated and an antigen retrieval step performed to expose the epitope (steroid receptor protein) under study. The sections were transferred into a Bond ${ }^{\mathrm{TM}}$ automated immunohistochemistry staining system (Vision BioSystems, Newcastle upon Tyne, UK). The immunostaining procedures were performed as described previously. ${ }^{17,20}$ The antigen-antibody complex was detected using a high-contrast polymer that included diaminobenzidine to identify positive immunoreactivity as indicated by presence of brown staining on tissue sections. Table 4 summarises the conditions for immunolocalisation of each of the epitopes studied.

\section{Scoring and analysis of immunoreactivity}

The immunostaining intensity of epitopes in all tissue sections was assessed in a standard semi-quantitative manner on a four-point scale: $0=$ no immunostaining, $1=$ mild immunostaining, $2=$ moderate immunostaining and 3 = intense immunostaining. All tissue sections were scored blind by two observers. We had previously validated this scoring system in a subset of tissue sections in which immunoreactivity was measured with a computerised image analysis system and a strong correlation between quantitative data derived from image analysis and subjective scores by a trained observer was obtained. ${ }^{21}$

\section{Statistics}

Multiple measurements on the same subjects in the same group were averaged before analysis. Wilcoxon signed-

Table 2 Group numbers and definitions

\begin{tabular}{llllll}
\hline Group & Women $(\boldsymbol{n})$ & Group definitions & & Biopsies $(\boldsymbol{n})$ \\
\cline { 3 - 5 } & & $\begin{array}{l}\text { Hormone replacement therapy } \\
\text { treatment }>\text { 3 months }\end{array}$ & $\begin{array}{l}\text { History of unscheduled } \\
\text { bleeding }\end{array}$ & $\begin{array}{l}\text { Bleeding at time } \\
\text { of endometrial biopsy }\end{array}$ \\
\hline 1 & 7 & No & No & No & 7 \\
2 & 8 & Yes & No & No & 9 \\
3 & 9 & Yes & Yes & Yes & 12 \\
4 & 9 & Yes & Yes & & 38 \\
Total & & & & & 38 \\
\hline
\end{tabular}


Table 3 Estrogen and progestogen components of hormone replacement therapy (HRT) preparations used

\begin{tabular}{|c|c|c|c|}
\hline Estrogen & Biopsies ( $n$ ) & Progestogen & Biopsies (n) \\
\hline Oral estradiol $1 \mathrm{mg}$ & 11 & Duphaston ${ }^{\circledR} 10 \mathrm{mg}$ & 4 \\
\hline Oral estradiol $2 \mathrm{mg}$ & 5 & Norethisterone acetate $250 \mu \mathrm{g}$ & 14 \\
\hline Transdermal estradiol $50 \mu \mathrm{g}$ & 10 & Cyproterone acetate $5 \mathrm{mg}$ & 1 \\
\hline Premarin ${ }^{\circledR} 0.625 \mathrm{mg}$ & 3 & Provera $^{\circledR} 5 \mathrm{mg}$ & 11 \\
\hline Premarin 1.25 mg & 2 & Provera $10 \mathrm{mg}$ & 1 \\
\hline Total biopsies from HRT users $(n)$ & 31 & & 31 \\
\hline
\end{tabular}

ranks tests were used for comparisons between Groups 3 and 4 for which the measurements were made on biopsies from the same subjects, while the other five pair-wise comparisons of groups (i.e. Group 1 vs Group 2, Group 1 vs Group 3, etc.) were made using Mann-Whitney tests since all subjects in Groups 1 and 2 differed from all those in Groups 3 and 4. Two subjects contributed data to both Groups 1 and 2, and their measurements were excluded from the comparison of these two groups. Dunn's multiple comparison correction was then applied to the $p$ values from each set of six tests.

\section{Ethical approval}

The study was approved by the institutional ethics committee of King Edward Memorial Hospital, WA, Australia and all subjects provided informed consent.

\section{Results}

Endometrial biopsies were separated into four groups on the basis of bleeding patterns. Of the 38 biopsies analysed, seven were from postmenopausal women not using HRT (18\%, Group 1), nine were from continuous combined HRT users with no bleeding in the previous 3 months $(24 \%$, Group 2), 12 were from continuous combined HRT users with a history of irregular bleeding in the previous 3 months $(31 \%$, Group 3) and 10 were from HRT users with irregular bleeding biopsied during a bleeding episode (26\%, Group 4) (Table 2). The median age of women not using HRT was 52 years [interquartile range (IQR) 49-57, range 45-59 years]. The median age of women on HRT was 54 years (IQR 53-57, range 42-62 years) and the median duration of HRT use was 34 months. There were no statistically significant differences between the ages of HRT users and non-users ( $p$ $=0.445$ ), time since menopause or body mass index of women between the groups. All HRT users were taking continuous combined HRT but as in normal clinical practice they were using a range of products (Table 3 ).

\section{Endometrial histology}

Of the 38 biopsies examined, 22/38 (58\%) were classified as weakly proliferative, $14 / 38(37 \%)$ were classified as atrophic, one appeared decidual and one appeared secretory. No relationship was observed between the histological appearance and bleeding patterns or to the type of estrogen or progestogen in the HRT used.

\section{Immunohistochemistry}

We examined the immunoexpression of PR, GR, AR, ER $\alpha$ and $\operatorname{ER} \beta$ at five cellular locations (i.e. in the endometrial glands, stroma, surface epithelium, vascular endothelium and in perivascular cells).

\section{PR immunoexpression}

\section{(Figures 1A, 2A and 2B, Table 5)}

No PR expression was observed in the vascular endothelium and perivascular cells in any of the biopsies. In the absence of HRT: moderate to intense PR expression was seen in the endometrial glands, stroma and surface epithelium.

In the HRT-treated endometrium: in all endometrial biopsies performed outside a bleeding episode, strong immunoexpression was observed in the endometrial glands, stroma and surface epithelium. The least amount of glandular PR expression was observed in women where the

Table 4 Immunohistochemistry protocols

\begin{tabular}{|c|c|c|c|}
\hline Protein of interest & Antigen retrieval & Primary antibody & Negative control \\
\hline Progesterone receptor (PR) & $\begin{array}{l}\text { Pressure-cook } \\
\text { Buffer: } 0.01 \mathrm{M} \\
\text { Na citrate pH } 6.0\end{array}$ & $\begin{array}{l}\text { Monoclonal mouse anti-PR } \\
\text { antibody } \\
\text { (Novocastra, Newcastle, UK) } \\
1: 400 \text { in BAD }\end{array}$ & $\begin{array}{l}\text { Mouse immunoglobulin } \\
\text { IgG (Sigma, Dorset, UK) } \\
1: 8000 \text { in BAD }\end{array}$ \\
\hline Glucocorticoid receptor (GR) & $\begin{array}{l}\text { Pressure-cook } \\
\text { Buffer: } 0.01 \mathrm{M} \\
\text { Na citrate } \mathrm{pH} 6.0\end{array}$ & $\begin{array}{l}\text { Monoclonal mouse anti-GR } \\
\text { antibody } \\
\text { (Novocastra, Newcastle, UK) } \\
1: 40 \text { in BAD }\end{array}$ & $\begin{array}{l}\text { Mouse immunoglobulin } \\
\text { IgG (Sigma, Dorset, UK) } \\
1: 320 \text { in BAD }\end{array}$ \\
\hline Androgen receptor (AR) & $\begin{array}{l}\text { Pressure-cook } \\
\text { Buffer: } 0.01 \mathrm{M} \\
\text { Na citrate pH } 6.0\end{array}$ & $\begin{array}{l}\text { Monoclonal mouse anti-AR } \\
\text { antibody } \\
\text { (Biogenex, CA, USA) } \\
1: 360 \text { in BAD }\end{array}$ & $\begin{array}{l}\text { Mouse immunoglobulin } \\
\text { IgG (Sigma, Dorset, UK) } \\
1: 450 \text { in } B A D\end{array}$ \\
\hline Estrogen receptor $\alpha(E R \alpha)$ & $\begin{array}{l}\text { Pressure-cook } \\
\text { Buffer: } 0.01 \mathrm{M} \\
\text { Na citrate } \mathrm{pH} 6.0\end{array}$ & $\begin{array}{l}\text { Monoclonal mouse anti-ER } \alpha \\
\text { antibody } \\
\text { (Dako, Cambridge, UK) } \\
1: 1200 \text { in BAD }\end{array}$ & $\begin{array}{l}\text { Mouse immunoglobulin } \\
\text { IgG (Sigma, Dorset, UK) } \\
1: 7200 \text { in BAD }\end{array}$ \\
\hline Estrogen receptor $\beta(E R \beta)$ & $\begin{array}{l}\text { Pressure-cook } \\
\text { Buffer: } 0.05 \mathrm{M} \\
\text { glycine } / 0.01 \% \text { EDTA }\end{array}$ & $\begin{array}{l}\text { Monoclonal mouse anti-ER } \beta \\
\text { antibody } \\
\text { (Serotec, Oxford, UK) } \\
\text { 1:40 in BAD }\end{array}$ & $\begin{array}{l}\text { BAD } \\
\text { Specificity of antibody as } \\
\text { previously reported }^{17}\end{array}$ \\
\hline
\end{tabular}

BAD, Bond ${ }^{\circledR}$ Antibody Diluent; EDTA, ethylenediaminetetraacetic acid. 
A

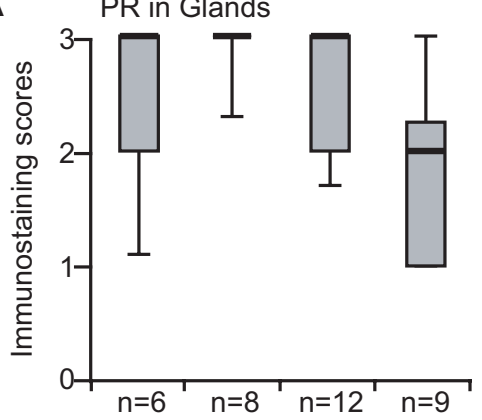

B

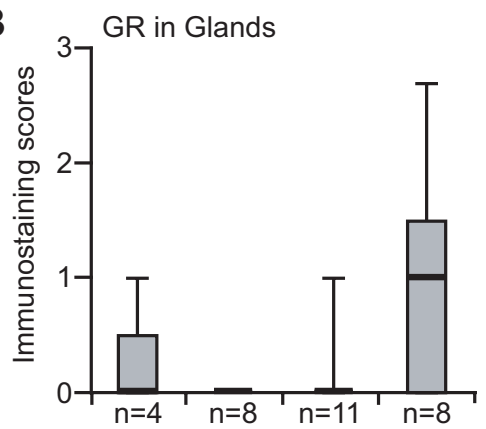

C

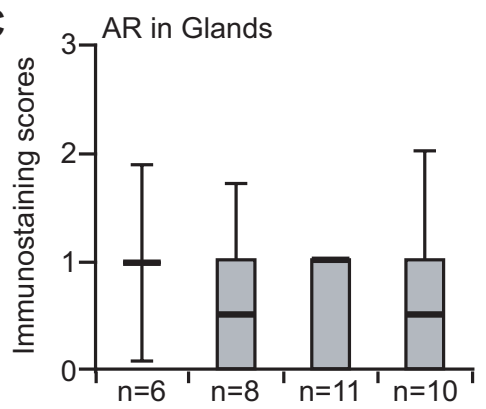

D

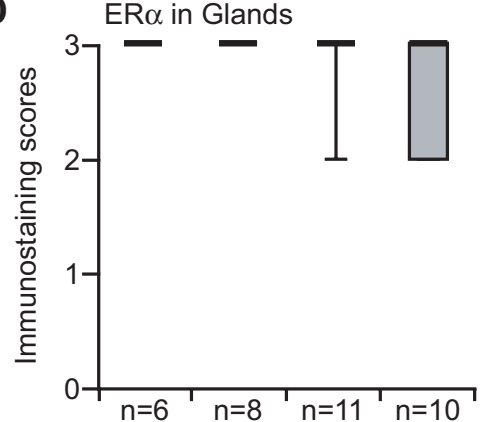

E

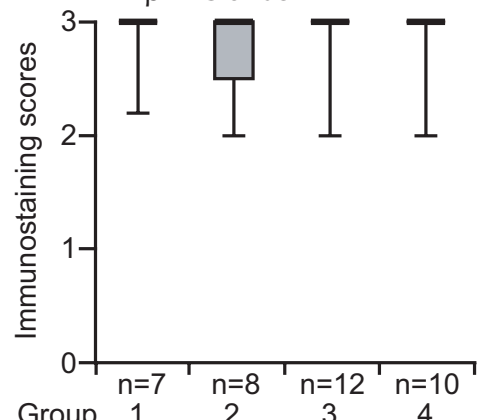

$\mathrm{PR}$ in Stroma
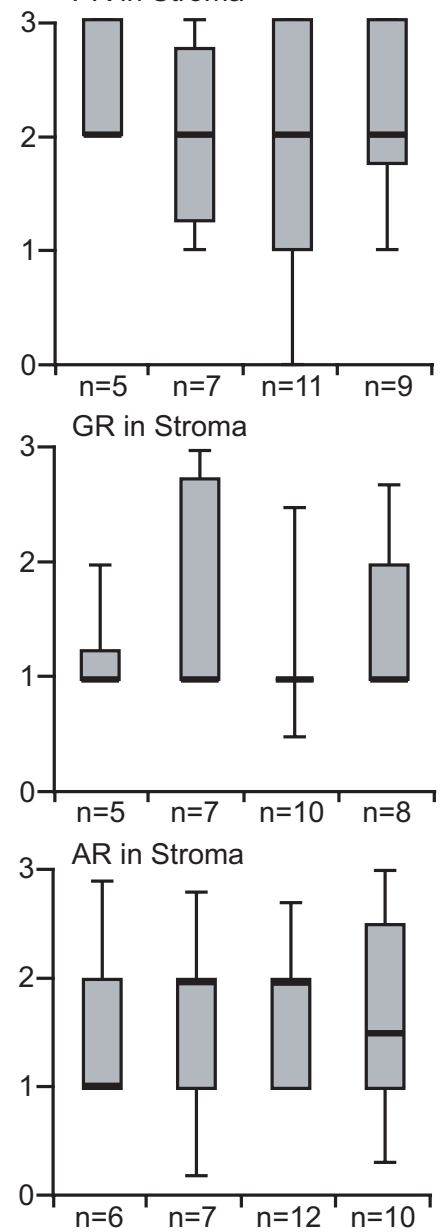

$\mathrm{ER} \alpha$ in Stroma

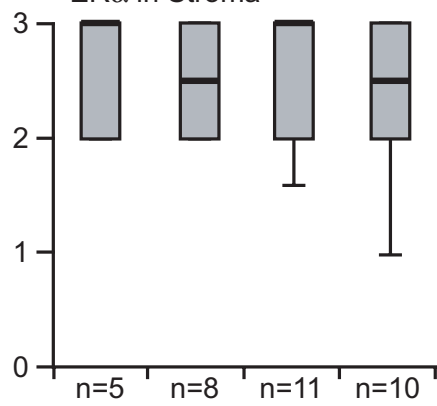

ER $\beta$ in Stroma

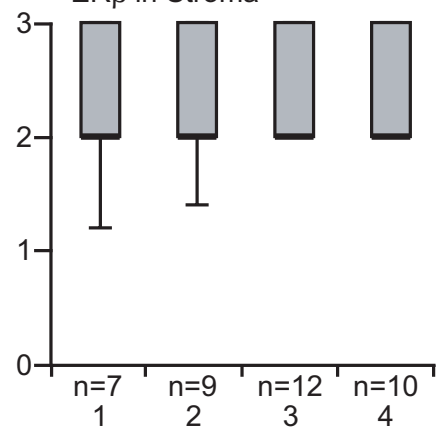

PR in Surface Epithelium

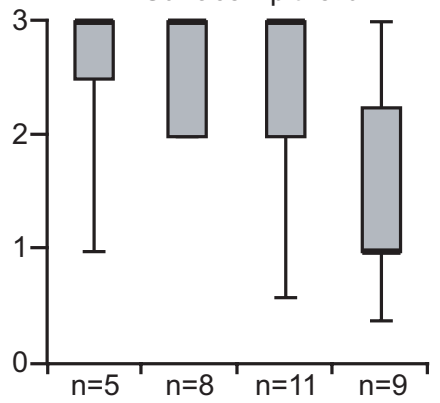

GR in Surface Epithelium

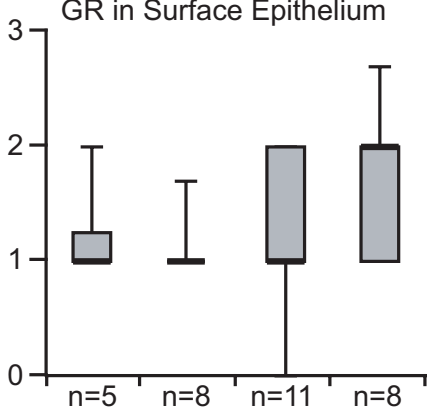

3 AR in Surface Epithelium

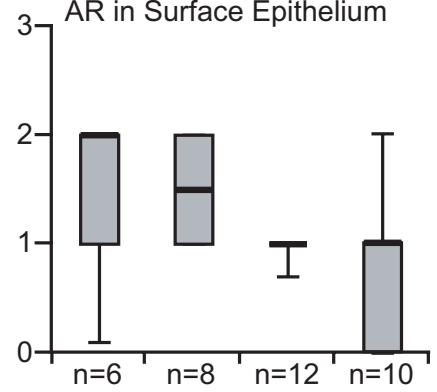

$\mathrm{ER} \alpha$ in Surface Epithelium

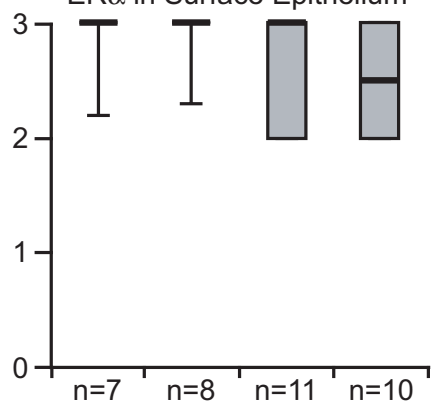

ER $\beta$ in Surface Epithelium

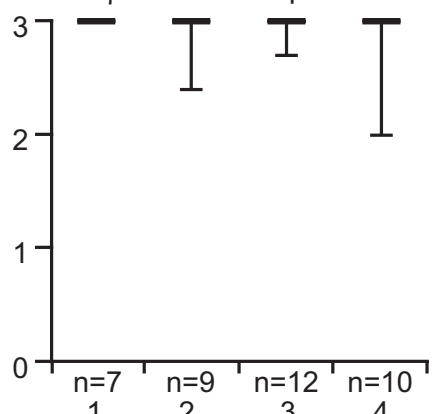

Figure 1 (A) Progesterone receptor (PR), (B) glucocorticoid receptor (GR), (C) androgen receptor (AR), (D) estrogen receptor $\alpha(E R \alpha)$ and (E) estrogen receptor $\beta(E R \beta)$. Semi-quantitative immunoreactivity scores in endometrial glands, stroma and surface epithelial compartments in four groups of women. Group 1: no hormone replacement therapy (HRT) use and no history of unscheduled bleeding. Group 2: HRT use $>3$ months with no history of unscheduled bleeding. Group 3: HRT use $>3$ months with a history of unscheduled bleeding. Endometrial biopsy conducted outside a bleeding episode. Group 4: HRT use $>3$ months with a history of unscheduled bleeding. Endometrial biopsy conducted during a bleeding episode. Box-and-whisker plots: box represents the 25th and 75th percentiles, whiskers represent the 10th and 90th percentiles and the heavy bar represents the median. NB. The $n$ numbers represent the total number of biopsies studied in each group. The $n$ numbers vary because in some biopsies that particular cell type was not reliably identified. 

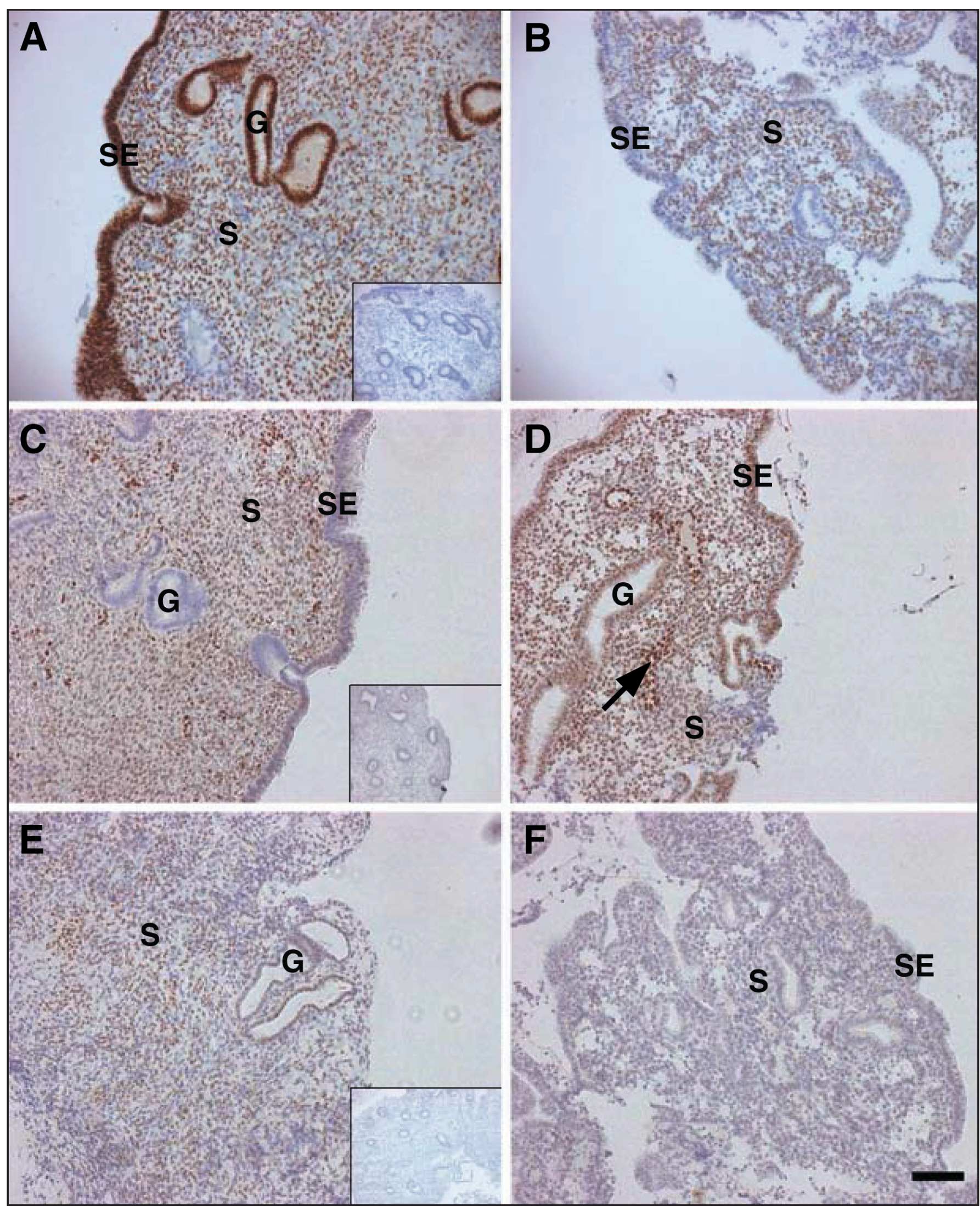

Figure 2 Immunohistochemical localisation of steroid receptors in human menopausal endometrium. Positive immunoreactivity indicating localisation of steroid receptor protein is indicated by brown staining. (A) Progesterone receptor (PR) immunostaining in endometrium from women on hormone replacement therapy (HRT) with no bleeding (Group 2). Note high level of glandular immunoreactivity. (A) Inset: PR negative control - no immunoreactivity. (B) PR immunostaining in endometrium from women on HRT with bleeding, biopsy conducted during a bleeding episode (Group 4) demonstrating decreased glandular immunoreactivity. (C) Glucocorticoid receptor (GR) immunostaining in endometrium from women on HRT with no bleeding (Group 2) illustrating down-regulation of glandular immunoreactivity. (C) Inset: GR negative control - no immunoreactivity. (D) GR immunostaining in endometrium from women on HRT with bleeding, biopsy conducted during a bleeding episode (Group 4) displaying increased glandular immunoreactivity. Note positive immunostaining in endothelial cells (arrow). (E) Androgen receptor (AR) immunostaining in endometrium from women not on HRT with no bleeding (Group 1). Note low level of immunoreactivity in glands and stroma. (E) Inset: AR-negative control - no immunoreactivity. (F) AR immunostaining in endometrium from women on HRT with bleeding, biopsy conducted during a bleeding episode (Group 4) illustrating low immunoreactivity in glands, stroma and surface epithelium. Scale bar $=50 \mu \mathrm{m}$. G, glands; S, stroma; SE, surface epithelium 
Table 5 Values of $p$ from the 90 statistical tests performeda

\begin{tabular}{lllllll}
\hline Tissue & Comparison & PR & GR & AR & ER $\boldsymbol{\alpha}$ & ER $\boldsymbol{\beta}$ \\
\hline Glandular & 1 vs 2 & 0.90 & 1.00 & 0.29 & 1.00 & 0.69 \\
& 1 vs 3 & 0.86 & 0.94 & 0.39 & 0.53 & 0.76 \\
& 1 vs 4 & 0.44 & 0.28 & 0.46 & 0.33 & 0.47 \\
& 2 vs 3 & 0.54 & 0.47 & 0.68 & 0.47 & 0.96 \\
& 2 vs 4 & $0.064^{\star}$ & $0.087^{\star}$ & 0.68 & 0.30 & 0.81 \\
& 3 vs 4 & $0.256^{\star}$ & 0.10 & 0.93 & 0.70 & 0.70 \\
Stroma & 1 vs 2 & 0.34 & 0.20 & 0.89 & 0.73 & 0.66 \\
& 1 vs 3 & 0.36 & 0.90 & 0.46 & 0.90 & 0.92 \\
& 1 vs 4 & 0.61 & 0.62 & 0.95 & 0.61 & 0.76 \\
& 2 vs 3 & 0.95 & 0.27 & 0.69 & 0.84 & 0.74 \\
& 2 vs 4 & 0.69 & 0.57 & 0.95 & 0.76 & 0.81 \\
& 3 vs 4 & 0.47 & 0.58 & 0.52 & 0.46 & 0.18 \\
Surface & 1 vs 2 & 0.41 & 0.73 & 0.90 & 1.00 & 1.00 \\
epithelium & 1 vs 3 & 0.44 & 0.90 & 0.09 & 0.35 & 0.84 \\
& 1 vs 4 & 0.11 & 0.22 & 0.18 & 0.21 & 0.84 \\
& 2 vs 3 & 0.68 & 0.76 & 0.11 & 0.35 & 0.84 \\
& 2 vs 4 & 0.06 & 0.12 & 0.14 & 0.21 & 0.76 \\
& 3 vs 4 & 0.12 & 0.17 & 0.74 & 0.76 & 0.32 \\
\hline
\end{tabular}

aFigures shown are uncorrected $p$ values from Mann-Whitney or Wilcoxon signed-ranks tests comparing each pair of study groups, except in the case of those asterisked $\left(^{*}\right)$ for which Dunn's correction was applied because the uncorrected $p$ values were significant.

$A R$, androgen receptor; $E R \alpha$, estrogen receptor $\alpha$; ER $\beta$, estrogen receptor $\beta$; GR, glucocorticoid receptor; PR, progesterone receptor.

endometrial biopsy was taken during a bleeding episode. In comparison to biopsies from women with no bleeding, biopsies performed during a bleeding episode showed a strong trend (non-significant) towards down-regulation of endometrial glandular PR expression $(p=0.064)$. The surface and glandular epithelia showed identical trends, while the stroma showed no differences between groups.

\section{GR immunoexpression}

\section{(Figures 1B, 2C and 2D, Table 5)}

In the absence of HRT: GR expression in the endometrial glands was negligible. Mild to moderate GR immunoreactivity was observed in the stroma, endothelium and surface epithelium.

In the HRT-treated endometrium: In biopsies obtained during a bleeding episode, a non-significant trend towards greater GR expression was observed in the endometrial glands compared to subjects with no bleeding $(p=0.087)$. The stromal expression of GR was variable. The immunoexpression in surface epithelium was mild to moderate in all groups of women, and more intense in the endothelium. Presence or absence of HRT, vaginal bleeding and the timing of the biopsy had no impact on the GR immunoexpression in the vascular endothelium and surface epithelium.

\section{AR immunoexpression}

\section{(Figures 1C, 2E and 2F, Table 5)}

In all the biopsies, AR expression in the endometrial perivascular cells and vascular endothelium was negligible. In the absence of HRT: mild AR expression was observed in the endometrial glands and stroma. AR expression in the surface epithelium was moderate.

In the HRT-treated endometrium: AR expression in the endometrial glandular epithelium and stroma in all groups of women was consistently at a low level.

\section{Estrogen receptor $\alpha$ and $\beta$ expression (Figures 1D and 1E, Table 5)}

In the absence of HRT: moderate to intense immunoreactivity for $\mathrm{ER} \alpha$ and $\mathrm{ER} \beta$ was observed in the endometrial glands, stroma, perivascular cells and surface epithelium. Only ER $\beta$ immunostaining was present in vascular endothelial cells.

In the HRT-treated endometrium: In all the groups of women, consistently strong ER $\alpha$ and ER $\beta$ expression was observed in the endometrial glandular epithelium, stroma and the surface epithelium.

\section{Discussion}

This study provides a detailed description of PR, GR, AR, $\mathrm{ER} \alpha$ and $\mathrm{ER} \beta$ receptor protein expression in endometrial cell components (glands, stroma, surface epithelium, perivascular and endothelial cells) of postmenopausal HRT users. Steroid receptor expression has been described in the context of bleeding patterns reported by subjects.

We have been unable to demonstrate significant differences in steroid receptor expression in endometrium of women using HRT who report unscheduled bleeding episodes.

We have described interesting trends (non-significant) in endometrial expression of glandular PR (decrease) and GR (increase) in postmenopausal HRT users who report unscheduled bleeding. These patterns of steroid receptor expression in HRT users (with and without unscheduled bleeding) differ from those seen in premenopausal women using progestogen-only contraception, with bleeding from an apparently 'atrophic' endometrium. Different mechanisms likely underlie abnormal bleeding in postmenopausal HRT users.

All HRT users in this study were using continuous combined HRT, which has a predominantly progestogenic effect on the endometrium. ${ }^{22}$ We might have expected to observe similar steroid receptor changes as those in the secretory phase of the normal menstrual cycle. In the latter, there is a down-regulation of ER $\alpha$ in the glands and stromal cells and of PR in glandular epithelium. ${ }^{15}$ The endogenous and exogenous hormonal milieu in postmenopausal HRT users is, however, quite different from that seen in the secretory phase in premenopausal women where the specific sequential pattern of ovarian steroid production is tightly regulated.

An interesting, albeit non-significant, observation was that with HRT, strong immunoexpression of PR in endometrial glands was maintained but in the presence of reported unscheduled bleeding glandular PR expression declined. Unlike the premenopausal state, in the postmenopausal untreated endometrium, strong glandular PR expression is maintained. In the absence of significant circulating levels of progestogens, the progestogenic stimulus to the endometrium is negligible. In regular cycling women, PR is down-regulated in the glandular compartment during the secretory phase by progesterone acting at both the transcriptional and post-transcriptional level.10,12 Since these were observational studies, we cannot confirm whether the reduction in PR was a cause or a result of unscheduled bleeding, or if present whether the PR is functional. In premenopausal women using long-acting progestogen-only contraceptives (POC), a decrease in PR is observed even after short-term use of progestogen but this has not been shown to relate to bleeding patterns. ${ }^{23,24}$ In depot medroxyprogesterone acetate users, stromal PR are reported to be reduced in those with irregular bleeding. 25 Another interesting observation was the absence of PR expression in the perivascular cells in all studied biopsies. No perivascular PR expression was observed irrespective of the presence or absence of HRT and with or without bleeding. This observation appears to be a feature of postmenopausal 
endometrium in contrast to premenopausal endometrium since, in the premenopausal state, at least in women with regular cycles, progesterone receptors are abundantly expressed in the perivascular endometrial cells throughout the cycle. ${ }^{14,15}$

The mechanisms of bleeding with both POC and HRT are not fully understood but the endometrial changes associated with bleeding in HRT users appear to show some differences to those seen in younger women with progestogen-related irregular bleeding, suggesting that different mechanisms may be involved.9,26 Dahmoun and colleagues have reported that PR expression in the epithelium and stroma is unchanged before and during HRT administration in subjects with no bleeding. ${ }^{27}$ Our findings are in agreement with this report, but we have the added advantage of samples from subjects with irregular bleeding patterns and also biopsies specifically obtained during a bleeding episode. The results from the present study add to the body of knowledge that bleeding episodes in HRT users are associated with distinct endometrial changes. We have previously demonstrated changes in endometrial leukocyte populations during bleeding in HRT users with an increase in uterine natural killer cells ${ }^{8}$ and changes in stromal expression of matrix metalloproteinases and their tissue inhibitors. 9,28

GR expression in endometrium is normally localised to stromal and endothelial cells. ${ }^{16,17}$ The role for GR and glucocorticoids in human endometrium has not been defined. Increased GR expression may potentiate effects of endogenous/locally derived cortisol thus suppressing angiogenesis 29,30 and aggravating potential for unscheduled bleeding. Augmented local cortisol action may also disturb local endometrial prostaglandin production. Prostaglandins play an important role in endometrial bleeding. ${ }^{31}$ Disturbance in the balance of local factors maintaining endometrial blood vessel integrity and stability could be another possible mechanism responsible for unscheduled bleeding.

In postmenopausal endometrium studied here there were no differences in AR or ER ( $\alpha$ and $\beta$ ) expression, irrespective of presence or absence of HRT and bleeding pattern. In postmenopausal untreated endometrium, Dahmoun and colleagues observed high levels of ER $\alpha$ expression in glandular epithelium but with HRT treatment a decrease in expression was seen. ${ }^{27}$ We did not observe any down-regulation of expression of $E R \alpha$ or $E R \beta$ in either glandular or stromal cells with HRT. Presence or absence of bleeding also did not make any significant difference to endometrial ER (ER $\alpha$ or ER $\beta$ ) expression. Dahmoun and colleagues used only two preparations of HRT in their study. ${ }^{27}$ In our study, five different preparations of continuous combined HRT preparations were used. This may have contributed to the differences in these findings. Alternatively it may suggest variable functional alterations of ER and PR in the postmenopausal endometrium during exposure to differing hormonal preparations.

We acknowledge that the sample size in our study is small. A reason why so few studies have addressed the mechanisms of irregular bleeding in HRT users is that adequate endometrial samples from postmenopausal women with no endometrial pathology and a thin endometrium can be extremely difficult to obtain. Furthermore, obtaining samples during a bleeding episode requires particular vigilance and a high level of compliance amongst postmenopausal women.

A variety of HRT preparations were used by the women taking part in this study. This may have influenced the endometrial cellular response. Nevertheless, irregular bleeding is common to all HRT preparations and hence it is reasonable to work on the assumption that common mechanisms may underlie these phenomena.

\section{Conclusions}

The present study of endometrial steroid receptor expression and bleeding patterns in HRT users has failed to demonstrate significant differences in steroid receptor protein expression in those women who report unscheduled bleeding episodes. These observations differ from the endometrial steroid receptor expression observed with normal menstruation and long-term progestogen-only administration, suggesting that different local mechanisms are involved in HRT-related bleedings.

We have observed, however, interesting trends (nonsignificant) in endometrial expression of glandular PR (decrease) and GR (increase) in postmenopausal HRT users who report unscheduled bleeding. These observations warrant further investigation among a larger group of HRT users with an endometrial biopsy during a bleeding episode to explore the mechanisms underlying problematic unscheduled bleeding. It is unlikely that effective strategies for the treatment or prevention of abnormal bleeding on HRT will be developed unless the underlying local mechanisms are understood.

\section{Statements on funding and competing interests}

Funding This study was funded by the National Health and Medical Research Council of Australia, Project Grant Number 254645 (MH). In Edinburgh, support was provided from MRC Grants G0000066 and G0500047 (HODC).

Competing interests None identified.

\section{Acknowledgements}

The authors would like to thank Teresa Henderson and Pamela Cornes for technical assistance with immunohistochemistry, Ted Pinner for assistance with graphics and Lee Ann Mahoney for patient recruitment. The authors are also very grateful to Rob Elton for expert statistical advice.

\section{References}

1 al-Azzawi F, Habiba M. Regular bleeding on hormone replacement therapy: a myth? Br J Obstet Gynaecol 1994; 101: 661-662.

2 Limouzin-Lamothe MA. What women want from hormone replacement therapy: results of an international survey. Eur $J$ Obstet Gynecol Reprod Biol 1996; 64: S21-S24.

3 Ettinger B, Li DK, Klein R. Unexpected vaginal bleeding and associated gynecologic care in postmenopausal women using hormone replacement therapy: comparison of cyclic versus continuous combined schedules. Fertil Steril 1998; 69: 865-869.

4 Elliott J, Connor ME, Lashen $\mathrm{H}$. The value of outpatient hysteroscopy in diagnosing endometrial pathology in postmenopausal women with and without hormone replacement therapy. Acta Obstet Gynecol Scand 2003; 82: 1112-1119.

5 Rossouw JE, Anderson GL, Prentice RL, LaCroix AZ, Kooperberg C, Stefanick ML, et al:; Writing Group for the Women's Health Initiative Investigators. Risks and benefits of estrogen plus progestin in healthy postmenopausal women: principal results From the Women's Health Initiative randomized controlled trial. JAMA 2002; 288: 321-333.

6 Mossa B, Imperato F, Marziani R, Perniola F, Melluso J, Perniola $\mathrm{G}$, et al. Hormonal replacement therapy and evaluation of intrauterine pathology in postmenopausal women: a ten-year study. Eur J Gynecol Oncol 2003; 24: 507-512.

7 North American Menopause Society. Role of progestogen in hormone therapy for postmenopausal women: position statement of the North American Menopause Society. Menopause 2003; 10: 113-132.

8 Hickey M, Crewe J, Goodridge CS, Witt CS, Fraser IS, Doherty $\mathrm{D}$, et al. Menopausal hormone therapy and irregular endometrial bleeding: a potential role for uterine natural killer cells? J Clin Endocrinol Metab 2005; 90: 5528-5535.

9 Hickey M, Crewe J, Mahoney LA, Doherty DA, Fraser IS, Salamonsen LA. Mechanisms of irregular bleeding with hormone therapy: the role of matrix metalloproteinases and their tissue inhibitors. J Clin Endocrinol Metab 2006; 91: 3189-3198.

10 Jabbour HN, Kelly RW, Fraser HM, Critchley HO. Endocrine regulation of menstruation. Endocr Rev 2006; 27: 17-46.

11 Smith OP, Critchley HO. Progestogen only contraception and endometrial break through bleeding. Angiogenesis 2005; 8: $117-126$ 
12 Chauchereau A, Savouret JF, Milgrom E. Control of biosynthesis and post-transcriptional modification of the progesterone receptor. Biol Reprod 1992; 46: 174-177.

13 Krikun G, Schatz F, Taylor R, Critchley HO, Rogers PA, Huang $J$, et al. Endometrial endothelial cell steroid receptor expression and steroid effects on gene expression. J Clin Endocrinol Metab 2005; 90: 1812-1818.

14 Perrot-Applanat M, Groyer-Picard MT, Garcia E, Lorenzo F, Milgrom E. Immunocytochemical demonstration of estrogen and progesterone receptors in muscle cells of uterine arteries in rabbits and humans. Endocrinology 1988; 123: 1511-1519.

15 Critchley HO, Brenner RM, Henderson TA, Williams K, Nayak NR, Slayden OD, et al. Estrogen receptor beta, but not estrogen receptor alpha, is present in the vascular endothelium of the human and nonhuman primate endometrium. J Clin Endocrinol Metab 2001; 86: 1370-1378.

16 Bamberger AM, Milde-Langosch $\mathrm{K}$, Loning T, Bamberger CM. The glucocorticoid receptor is specifically expressed in the stromal compartment of the human endometrium. J Clin Endocrinol Metab 2001; 86: 5071-5074.

17 Henderson TA, Saunders PT, Moffett-King A, Groome NP Critchley $\mathrm{HO}$. Steroid receptor expression in uterine natural killer cells. J Clin Endocrinol Metab 2003; 88: 440-449.

18 Mertens HJ, Heineman MJ, Theunissen PH, de Jong FH, Evers $\mathrm{JL}$. Androgen, estrogen and progesterone receptor expression in the human uterus during the menstrual cycle. Eur $J$ Obstet Gynecol Reprod Biol 2001; 98: 58-65.

19 Noyes RW, Hertig AT, Rock J. Dating the endometrial biopsy. Fertil Steril 1950; 1: 3-25.

20 Burton KA, Henderson TA, Hillier SG, Mason JI, Habib F, Brenner RM, et al. Local levonorgestrel regulation of androgen receptor and 17beta-hydroxysteroid dehydrogenase type 2 expression in human endometrium. Hum Reprod 2003; 18: 2610-2617.

21 Wang H, Critchley HO, Kelly RW, Shen D, Baird DT. Progesterone receptor subtype $B$ is differentially regulated in human endometrial stroma. Mol Hum Reprod 1998; 4: 407-412.

22 Wells M, Sturdee DW, Barlow DH, Ulrich LG, O'Brien K, Campbell MJ, et al. Effect on endometrium of long term treatment with continuous combined estrogen/progestogen replacement therapy; follow up study. BMJ 2002; 325: 239-242.

23 Critchley HO, Wang H, Kelly RW, Gebbie AE, Glasier AF. Progestin receptor isoforms and prostaglandin dehydrogenase in the endometrium of women using a levonorgestrel-releasing intrauterine system. Hum Reprod 1998; 13: 1210-1217.

24 Hurskainen R, Salmi A, Paavonen J, Teperi J, Rutanen E. Expression of sex steroid receptors and $\mathrm{Ki}-67$ in the endometria of menorrhagic women: effects of intrauterine levonorgestrel. Mol Hum Reprod 2000; 6: 1013-1018.

25 Chotnopparatpattara P, Taneepanichskul S, Treratanachat S, Charuruks N. Relationship between progesterone receptor level in endometrium and bleeding pattern in depot medroxyprogesterone acetate users. J Med Assoc Thai 2003; 86: $172-177$

26 Hickey M, Pillai G, Higham JM, Sullivan M, Horncastle D, Doherty $\mathrm{D}$, et al. Changes in endometrial blood vessels in the endometrium of women with hormone replacement therapyrelated irregular bleeding. Hum Reprod 2003; 18: 1100-1106.

27 Dahmoun M, Odmark IS, Risberg B, Karlsson MG, Pavlenko T, Backstrom T. Apoptosis, proliferation, and sex steroid receptors in postmenopausal endometrium before and during HRT. Maturitas 2004; 49: 114-123.

28 Hickey M, Higham J, Sullivan M, Miles L, Fraser IS. Endometrial bleeding in hormone replacement therapy users: preliminary findings regarding the role of matrix metalloproteinase 9 (MMP. 9) and tissue inhibitors of MMPs. Fertil Steril 2001; 75: 288-296.

29 Narvekar N, Critchley HO, Cheng L, Baird DT. Mifepristoneinduced amenorrhoea is associated with an increase in microvessel density and glucocorticoid receptor and a decrease in stromal vascular endothelial growth factor. Hum Reprod 2006; 21: 2312-2318.

30 Small GR, Hadoke PW, Sharif I, Dover AR, Armour D, Kenyon $\mathrm{CJ}$, et al. Preventing local regeneration of glucocorticoids by 11 beta-hydroxysteroid dehydrogenase type 1 enhances angiogenesis. Proc Natl Acad Sci USA 2005; 102 $12165-12170$.

31 Baird DT, Cameron ST, Critchley HO, Drudy TA, Howe A, Jones $\mathrm{RL}$, et al. Prostaglandins and menstruation. Eur J Obste Gynecol Reprod Biol 1996; 70: 15-17.

\section{FACULTY MEMBERSHIP EXAMINATION}

The Membership Examination (MFSRH, formerly MFFP) consists of

\section{Part 1 Multiple Choice Question paper (MCQ)}

This 11/2-hour paper consists of 60 clinical science and applied science questions.

The examination will be held in London on Wednesday 23 April 2008 and Friday 17 October 2008.

Applications for April 2008 must be received by 1 January 2008 and those for October 2008 must be received by 1 July 2008. The application form and information on the Part 1 can be obtained from the Faculty of Sexual and Reproductive Healthcare website (www.fsrh.org).

\section{$\square$ Dissertation or Case Reports}

Submission of one Dissertation (10 000 words) or two Case Reports (3000 words each).

Please visit the Faculty of Sexual and Reproductive Healthcare website (www.fsrh.org) for information and forms for this component of the examination, and for information on exemptions.

\section{Part 2 Examination (CRQ, SAQ, OSCE)}

This all-day examination consists of:
- Critical Reading Question examination paper (CRQ)
- Short Answer Question examination paper (SAQ)
- Objective Structured Clinical Examination (OSCE)

Applications for the MFSRH Part 2 to be held on 5 June 2008 must be received by 3 January 2008. Information on the Part 2 Examination, the Examination Regulations and the application form appear on the Faculty of Sexual and Reproductive Healthcare website (www.fsrh.org).

The qualification is subject to re-certification every 5 years.

For the MFSRH Examination Regulations (November 2007), information on all components of the MFSRH Examination and application forms, please visit the Faculty of Sexual and Reproductive Healthcare website: www.fsrh.org (see Training \& Exams and Membership Exam), or contact: Denise Pickford, e-mail: denise@fsrh.org, Examinations, Faculty of Sexual and Reproductive Healthcare of the Royal College of Obstetricians and Gynaecologists, 27 Sussex Place, Regent's Park, London NW1 4RG, UK. Tel: +44 (0) 207724 5629. Fax: +44 (0) 2077235333. 